Paideusis

\title{
"Key Questions for Educators" (William Hare and John P. Portelli (Eds.))
}

\section{Donald Kerr}

Volume 15, Number 2, 2006

URI: https://id.erudit.org/iderudit/1072685ar

DOI: https://doi.org/10.7202/1072685ar

See table of contents

Publisher(s)

Canadian Philosophy of Education Society

ISSN

0838-4517 (print)

1916-0348 (digital)

Explore this journal

Cite this review

Kerr, D. (2006). Review of ["Key Questions for Educators" (William Hare and John P. Portelli (Eds.))]. Paideusis, 15(2), 107-108.

https://doi.org/10.7202/1072685ar viewed online.

https://apropos.erudit.org/en/users/policy-on-use/ 


\section{Review of}

\section{Key Questions for Educators}

by William Hare and John P. Portelli (Eds.), Halifax, Nova Scotia: Edphil Books, 2005.

DONALD KERR

Lakehead University, Canada

Key Questions for Educators is a collection of forty short essays introducing a variety of important educational ideas, aims and approaches, each in answer to the question 'What is (the particular idea)?' These cover a broad range of topics, from the general - education itself, knowledge, and imagination, for example - through areas of theoretical background - postmodernism, curriculum, constructionism, educational theory - to specific areas of concern and contemporary pedagogical issues - democratic education, multiculturalism, accountability, marketization and character education. The essays were written specifically for this volume, by leading commentators on each of the topics. The forty contributors represent an international cross-section of researchers, with a heavy inclusion of Canadian theorists.

The contributions also reflect a variety of approaches to describing and discussing concepts in education. So Nel Noddings, describing care, and William Hare, describing openmindedness, each provides a clear description of the prevalent understanding of their topics - in both of these cases, the author's own. Candace Jesse Stout tells a story around the production of an imaginative work in a school as a way of eliciting some of the main characteristics of imagination.

Richard Smith works through ways of approaching the question of 'What is Education?' to give both a sense of some of the main concerns in thinking about education, and an initial introduction to approaching questions of definition. Maureen Ford describes postmodernity by giving some sense of what modernity means; she starts by drawing, as a metaphor for postmodernity as an idea, a verbal picture of a post-modern building. She also concludes by playfully suggesting that a better question than 'What is postmodernity?' might be 'How is postmodernity?'

This book would be useful for informing an undergraduate class on foundations of education; it provides a worthwhile introduction to many important topics in the field. A useful way to use this text would be to ask students how their understanding of what happens in a classroom might be changed given what is said about a particular concept. This collection thus not only provides necessary background knowledge on important concepts, but can also be used to help students understand how ideas shape education - a seemingly obvious connection, but one that often does not seem to be given much thought by students in teacher education. Each essay is supported with three suggestions for further reading, giving students a good start for further study. The examples above of the many different ways the contributors have approached their topics suggests another use of this text would be as an introduction to the many ways that theorists attempt to work out and explain challenging ideas, and an invitation to consider the successes and difficulties with different approaches.

The extent to which authors point out the pedagogical importance of particular concepts varies. For instance, Sharon Bailin's description of critical thinking is quite prescriptive, whereas Daniel Vokey's discussion of spiritual education raises implications of this for educators to consider, but is not

(C) Copyright 2006. The author, Donald Kerr, assigns to Paideusis the right of first publication and educational and non-profit institutions a non-exclusive license to use this document for personal use and in courses of instruction provided that the article is used in full and this copyright statement is reproduced. Any other usage is probibited without the express permission of the author. 
pedagogically prescriptive. Many of the other descriptions are not pedagogically prescriptive at all - as indeed it is hard to imagine how they would be.

One of the entries that I find less effective is Shirley Steinberg's entry on professionalism. Steinberg proceeds by listing characteristics that professionalism is not. This of course can be a useful strategy for working out what we might mean or want to mean by the concept in the positive (as but one example, Richard Smith employs the strategy in refining what we mean by education), but it is not clear how much can be gleaned by claiming that professionalism is not easy, or is not predictable. Why is it not? What is it about professionalism that makes it not easy, or likely unpredictable? If professionalism is not easy or predictable or a host of other things just what is at the core of the idea of professionalism that is left? In fact, it seems to me that professionalism may often be very predictable but resolving this will depend on a much closer working out of just what we mean or want to mean by the term. This entry is less successful because it lacks the clear attempt at exposition of just what the main idea - professionalism - is, or might be, that almost all the essays in this collection have. But in this regard the essay is useful, too - both for indicating the body of work and breadth of thinking on leadership, as well as providing an example for discussion of why a particular description may be unsatisfying to some. That the occasional less than satisfying entry in this book stands out is testament to the generally very high quality of the included essays.

One question of a collection such as this is of its breadth, and how well it represents the field today. On this question I think this book is exceptionally strong. I have already given some indication of the breadth of the topics in the book, and these cover most of the main areas of current concern, outside of psychology and specific curricular mandates, of the field and of teachers. So one might quibble that a particular area of concern is not fully represented: for instance, I wonder why there's no entry on liberalism, the major theoretical underpinning of our beliefs about education today. At the same time, among others, Wendy Kohli's entry on social justice education, Eamonn Callan's essay on citizenship education, and to a lesser extent Ronald David Glass' introduction to democratic education all make reference to the liberal principles underlying these areas of concern, and so there is an important sense in which this topic is already well represented.

One minor quibble I have with this book is its set-up: it is not clear to me why it is introduced and entitled the way it is. While we should ask of any idea that is new to us what is meant by the idea, once we get beyond our initial search for understanding each idea opens up a host of new questions. That is, a collection of key questions for educators would likely include pedagogical and historical questions, among others - such as what is the latest thinking on how certain goals are best achieved, or why does our form of schooling look just as it does? So it is not entirely clear why the volume is entitled Key Questions rather than something like Key Ideas, nor why each chapter title is framed as a question.

This trivial point aside, it is easy to praise this book. It is easily accessible (and small enough) such that it would be very useful (and handy) to the student new to the field; at the same time readers gain access to introductions to topics by some of the leading thinkers in education. While each essay has been kept to about 1000 words, the essays are in the main uniformly strong. William Hare and John Portelli have once again done an excellent service to the study of foundations by putting together this text. 